\title{
Políticas Públicas de Educação Ambiental no Brasil: um panorama a partir de eventos internacionais e nacionais
}

\author{
Public Policies of Environmental Education in Brazil: An overview from international and national \\ events
}

Políticas Públicas de Educación Ambiental en Brasil: Un panorama a partir de eventos

internacionales y nacionales

Recebido: 05/06/2021 | Revisado: 10/06/2021 | Aceito: 10/06/2021 | Publicado: 26/06/2021

\author{
Diego Andrade de Jesus Lelis \\ ORCID: https://orcid.org/0000-0002-4419-2978 \\ Pontifícia Universidade Católica do Paraná, Brasil \\ E-mail: diegolellis09@ hotmail.com \\ Ronualdo Marques \\ ORCID: https://orcid.org/0000-0001-6681-9914 \\ Universidade Federal do Paraná, Brasil \\ E-mail: ronualdo.marques@gmail.com
}

\begin{abstract}
Resumo
Este estudo apresenta uma revisão analítica da agenda de Políticas Públicas da Educação Ambiental no Brasil a partir dos eventos internacionais e nacionais. Tem por objetivo apresentar e elencar as contribuições para formulação, inserção e implementação destas para a educação formal, não formal e informal. Metodologicamente, trata-se de uma pesquisa qualitativa com análise documental e de natureza interpretativa a partir da problemática ambiental que tornou pauta efetiva para as Políticas Públicas a partir da segunda metade do século XX. Observou-se que a agenda da Educação Ambiental no Brasil está em constantes transformações, (re) formulações e (re) construção a qual se infere a Educação Ambiental como dimensão da educação possui uma força importante para o processo de sensibilização e conscientização nas relações que emergem entre homem, sociedade e natureza.
\end{abstract}

Palavras-chave: Educação ambiental; Políticas públicas; Educação.

\begin{abstract}
This study presents an analytical review of the Public Policy Agenda of Environmental Education in Brazil from international and national events. It aims to present and list the contributions to the formulation, insertion and implementation of these for formal education, non-formal and informal. Methodologically, it is a qualitative research with documentary analysis and interpretative nature from the environmental problem that became effective agenda for Public Policy from the second half of the twentieth century. It was observed that the agenda of Environmental Education in Brazil is in constant transformations, (re)formulations and (re)construction which infers that Environmental Education as dimension of education has an important force for the process of sensitization and awareness in relations that emerge between man, society and nature.
\end{abstract}

Keywords: Environmental education; Public policies; Education.

\section{Resumen}

Este estudio presenta una revisión analítica de la agenda de Políticas Públicas de Educación Ambiental en Brasil a partir de eventos internacionales y nacionales. Su objetivo es presentar y enumerar las contribuciones a la formulación, inserción y aplicación de las mismas para la educación formal, no formal e informal. Metodológicamente, se trata de una investigación cualitativa con análisis documental y carácter interpretativo a partir de la problemática ambiental que se convirtió en agenda efectiva de Políticas Públicas a partir de la segunda mitad del siglo XX. Se observó que la agenda de la Educación Ambiental en Brasil está en constantes transformaciones, reformulaciones y reconstrucciones lo que infiere que la Educación Ambiental como dimensión de la educación tiene una fuerza importante para el proceso de concientización y sensibilización en las relaciones que surgen entre el hombre, la sociedad y la naturaleza.

Palabras clave: Educación ambiental; Políticas públicas; Educación. 


\section{Introdução}

O Meio ambiente assim como os diversos setores da sociedade sofreu inúmeras transformações ao logo da história. Nesse sentido, frente a estas transformações e impulso do sistema capitalista para forjar o desenvolvimento dos países, temos a Educação Ambiental - EA surge como elemento a pensar e repensar o modelo de desenvolvimento que cause o menor impacto sobre a vida humana. Dessa forma, esse estudo teve como objetivo elencar os principais acontecimentos que impulsionaram essas transformações, bem como os rumos que foram sendo tomados em nível mundial por meio das conferências e cúpulas e em nível nacional através das diretrizes, leis e criação de organismos no campo do meio ambiente e da EA.

Ao se considerar a importância da Educação Ambiental como dimensão da educação, é necessário ter em mente que ela surgiu no cenário internacional e depois nacional a partir de uma preocupação global em relação ao meio ambiente. Para efeito de contextualização, situamos nossa discussão a partir da história moderna e contemporânea que se registraram 4 grandes revoluções industriais. O século XX traz em seu contexto histórico, político, econômico, social e geográfico duas Guerras Mundiais e a Guerra Fria. A supremacia do modelo capitalista sobre o modelo socialista de economia. A hegemonia dos países do Norte sobre os países do Hemisfério Sul.

Todos esses fatores devem ser levados em consideração ao abordar o processo de desencantamento do ser humano em relação as crenças cósmicas e a metafísica, e sobretudo, a temática ambiental e as concepções de relações entre o ser humano e a natureza e desse com seus pares.

\section{Metodologia}

Este O objetivo desta pesquisa foi buscar fundamentos a partir da revisão de literatura sobre as orientações políticopedagógica, filosóficas e epistemológicas na formulação, inserção, implementação das Políticas Públicas da Educação Ambiental na educação formal, não-formal e informal de a partir dos principais eventos internacionais e nacionais que colocam a Educação Ambiental no cerne do debate e que influenciará o desenvolvimento dos países nas questões culturais, econômicas, educacionais entre outras, partindo do pressuposto da preocupação incessante perante a complexa dinâmica das relações entre homem, sociedade e natureza, onde se torna evidente e necessária a sua presença na formulação de Políticas Publicas que possibilitem uma harmonia ente os diversos setores da sociedade e quem causem o mínimo de impactos ao meio ambiente. Assim a pesquisa tem sua,

Tomada num sentido amplo, pesquisa é toda atividade voltada para a solução de problemas; como atividade de busca, indagação, inquirição da realidade, é a atividade que vai nos permitir, no âmbito da ciência, elaborar um conhecimento, ou um conjunto de conhecimentos, que nos auxilie na compreensão desta realidade e nos oriente em nossas ações (Pádua, 1997, p. 29).

Para cumprimento do objetivo proposto foi adotada estratégia metodológica qualitativa, utilizando-se a técnica de levantamento e análise documental (Calado; Ferrera, 2015). A pesquisa qualitativa, segundo Higgs; Cherry (2009) refere-se a avaliações e interpretações críticas e qualitativas, sobre a proposta.

Para Ludke e André (2015), o procedimento do pesquisador na abordagem qualitativa é estar atento à multiplicidade de dimensões de uma determinada situação ou problema e após a análise dos dados, ele lança possibilidades de explicação da realidade, tentando encontrar princípios subjacentes ao fenômeno estudado e situar as suas descobertas num contexto mais amplo; trata-se de um esforço de construção ou estruturação de um quadro teórico, dentro do qual o fenômeno possa ser interpretado e compreendido.

Nesse sentido, buscamos os principais eventos internacionais e nacionais conforme Quadro 1 e tentou-se trazer quais as contribuições de cada um para a formulação, inserção e implementação da Educação Ambiental para o país. 
Quadro 1. Principais marcos históricos internacionais e nacionais da Educação Ambiental.

\begin{tabular}{|c|c|}
\hline Acontecimento/ano & Abrangência \\
\hline Publicação da obra "Primavera Silenciosa" pela bióloga Rachel Carson - 1962 & Internacional \\
\hline É utilizado pela primeira vez o termo Educação Ambiental (1965) & Internacional \\
\hline Fundação do Clube de Roma (1968) & Internacional \\
\hline Divulgação do Relatório do Grupo de Roma (1972) & Internacional \\
\hline Conferência de Estocolmo (1972) & Internacional \\
\hline Criação da Secretaria Especial de Meio Ambiente-SEMA (1973) & Nacional \\
\hline Conferência de Belgrado (1975) & Internacional \\
\hline Programa Internacional de Educação Ambiental-PIEA (1975) & Internacional \\
\hline Conferência de Tbilisi (1977) & Internacional \\
\hline Documento diretor sobre as diretrizes da EA no Brasil (1977) & Nacional \\
\hline Lei 6938/81 Estabelece a Política Nacional de Meio Ambiente - PNMA (1981) & Nacional \\
\hline Congresso Internacional de Moscou (1987) & Internacional \\
\hline Parecer do MEC Nº 226/87 (1987) & Nacional \\
\hline Promulgação da Constituição Federal Brasileira (1988) & Nacional \\
\hline Criação do Fundo Nacional de Meio Ambiente (1989) & Nacional \\
\hline Conferência de Jomtein (1990) & Internacional \\
\hline Portaria do MEC nº 678/91 (1991) & Nacional \\
\hline Criação do Ministério do Meio Ambiente (1992) & Nacional \\
\hline Instituição dos núcleos de EA em todos os Estados do País (1992) & Nacional \\
\hline Conferência das Nações Unidas sobre o Meio Ambiente e Desenvolvimento Rio-92 (1992) & Nacional e Internacional \\
\hline Carta Brasileira para a Educação Ambiental (1992) & Nacional \\
\hline Criação do Programa Nacional de Educação Ambiental - PRONEA (1994) & Nacional \\
\hline Conferência de Tessalônica (1997) & Internacional \\
\hline Publicação dos PCN'S (1997) & Nacional \\
\hline $1^{\text {a }}$ Conferência de Educação Ambiental no Brasil (1997) & Nacional \\
\hline Diretrizes Curriculares Nacionais para o Ensino Fundamental (1998) & Nacional \\
\hline Aprovação da Lei Federal n ${ }^{\circ} 9.795 / 1999$ & Nacional \\
\hline Conferência de Joanesburgo / Rio+10 (2002) & Internacional \\
\hline Reorganização do Programa Nacional de Educação Ambiental (2004) & Nacional \\
\hline Rio+20 (2012) & Nacional e Internacional \\
\hline $\begin{array}{l}\text { Resolução } n^{\circ} 02 \text {, de } 15 \text { de junho de 2012, estabelece as Diretrizes Curriculares Nacionais para a } \\
\text { Educação Ambiental (2012). }\end{array}$ & Nacional \\
\hline $\begin{array}{l}\text { Programa Nacional de Escolas Sustentáveis - versão } \\
\text { preliminar (2014). }\end{array}$ & Nacional \\
\hline Programa Nacional de Educação Ambiental (ProNEA) - 5 edição (2018) & Nacional \\
\hline
\end{tabular}

Fonte: Elaborado pelos autores.

\section{Resultados e Discussão}

Os Embora o meio ambiente faça parte da vida humana desde a sua origem, as questões que envolvem a problemática do meio ambiente e a EA só tomaram maiores proporções e ocuparam o rol das temáticas de discussões políticas, científicas e acadêmicas na segunda metade do século XX.

Os protestos e manifestações questionando os valores da sociedade capitalista e problemas de ordem social e políticas que ocorreram nos anos 50 e 60, criaram um clima favorável para o envolvimento da sociedade civil e impulsionaram o fortalecimento dos movimentos sociais em torno dos quais se agrega e amplia o ambientalismo, e se ergue a bandeira da ecologia (Ramos, 2001 p. 202).

Corroborando com essa idéia Silva; Oliveira (2019, p. 278) afirmam que "os problemas ambientais, na década de 1960, mostravam a irracionalidade do modelo econômico, iniciado após as grandes Revoluções Industriais". Neste sentido, apresenta-se como um marco dessa preocupação, denúncia e envolvimento da sociedade a publicação da obra intitulada "Primavera Silenciosa" pela bióloga Rachel Carson nos Estados Unidos da América. 
Na visão de Oliveira (2013, p.26) a referida obra traz a denúncia sobre o modo de relação predatória que o ser humano tem estabelecido com a natureza. Sobre isso, Saccomani et al., (2018, p. 739) afirma que "este livro foi considerado um marco no movimento ambientalista, na década de 1970 e, até hoje, é uma referência teórica".

No que se refere a EA propriamente dita, conforme Oliveira (2013, p. 28) "em março de 1965, na Grã-Bretanha, na Conferência em Educação, pela Universidade de Keele, foi proposto o termo Educação Ambiental". O termo foi proposto pelo filósofo e médico Alemão Albert Schwitzer.

Segundo Silva; Oliveira (2019, p. 279) "no ano de 1968, diversos cientistas encontraram-se na cidade de Roma para discutir sobre as reservas naturais não renováveis e o crescimento populacional no âmbito mundial”. Esse grupo denominado como Clube de Roma foi responsável pela realização de relatórios alertando para a exaustão da natureza.

Os encontros do Clube de Roma foram concebidos, em 1968, pelo industrial italiano Aurélio Peccei, e patrocinados por grandes empresas como a FIAT e a Volkswagen. No início dos anos setenta, os encontros reuniam cerca de setenta cientistas, acadêmicos, economistas, industriais e membros de instituições públicas de países desenvolvidos (Corrêa Do Lago, 2007, p. 28).

Em 1972 o grupo divulgou um relatório intitulado "os limites do crescimento" anunciando que "era preciso impor limites tanto para o crescimento e desenvolvimento econômico, como para o crescimento da população, visto que os recursos naturais eram finitos" (Ramos, 2001, p. 203).

Concomitante ao lançamento do relatório, ocorreu em Estocolmo, capital da Suécia, a $1^{\text {a }}$ Conferência da Organização das Nações Unidas - ONU sobre o ambiente humano. Como resultado das discussões realizadas pelos 113 países participantes, foi lançada a Declaração sobre o Ambiente Humano.

Esse documento apresenta princípios norteadores para que os governantes os ponham em prática a partir de sua realidade, atestando que os países desenvolvidos devem reconhecer a sua ampla contribuição no processo de degradação do planeta, e por isso, devem comprometer-se com a desaceleração da exploração dos recursos naturais.

Aos países em desenvolvimento coube a reflexão em vista de promover ações frente a realidade da pobreza, da fome e da falta de moradia, visto que "a maioria dos problemas ambientais estão motivados pelo subdesenvolvimento" (Estocolomo, 1972).

Embora o documento represente um avanço nas discussões sobre a temática, o pano de fundo está na preservação da natureza em função da manutenção da vida humana e do desenvolvimento financeiro dos países. Os princípios orientadores estabelecidos direcionam-se para a gestão dos recursos naturais, visto que o esgotamento significaria o desaparecimento da raça humana.

A percepção da natureza como um bem em si mesma não aparece no documento. "Nesta conferência, observou-se a defesa de perspectivas radicais, com sentidos opostos, embora balizadas por valores preservacionistas e conservacionistas" (Ramos, 2001, p. 204). A concepção de natureza como recurso está evidente nos princípios que seguem:

\section{Princípio 2}

Os recursos naturais da terra incluídos o ar, a água, a terra, a flora e a fauna e especialmente amostras representativas dos ecossistemas naturais devem ser preservados em benefício das gerações presentes e futuras, mediante uma cuidadosa planificação ou ordenamento.

Princípio 5

Os recursos não renováveis da terra devem empregar-se de forma que se evite o perigo de seu futuro esgotamento e se assegure que toda a humanidade compartilhe dos benefícios de sua utilização.

Princípio 7

Os Estados deverão tomar todas as medidas possíveis para impedir a poluição dos mares por substâncias que possam pôr em perigo a saúde do homem, os recursos vivos e a vida marinha, menosprezar as possibilidades de derramamento ou impedir outras utilizações legítimas do mar (Estocolomo, 1972). 
Ao encaminhar as reflexões por essa égide a Conferência põe no rol das discussões a conscientização para o que atualmente entendemos por desenvolvimento sustentável. Nesta perspectiva, reafirma-se a partir dos estudos de Timoteo (2016, p. 20) que, em virtude dos estudos e discussões realizadas, o evento "teve grande importância ao inaugurar a busca por equilíbrio entre desenvolvimento econômico e redução da degradação ambiental, que mais tarde evoluiria para a noção de desenvolvimento sustentável".

É importante destacar que dentre as soluções propostas para a problemática, compreendeu-se a necessidade recorrer a educação como instrumento de transformação da realidade. Assim, "manifesta-se a necessidade de mudança na intervenção do meio ambiente, e entende-se que isso é possível pela Educação Ambiental (Ramos, 2001, p. 204)”.

Corroborando com essa afirmação Moradillo; Oki (2004, p. 332) afirmam que "a Conferência de Estocolmo marcou, no nível internacional, a necessidade de políticas ambientais, reconhecendo a Educação Ambiental como uma necessidade para a solução dos problemas ambientais". O texto da declaração conclama que a EA seja direcionada à todas as pessoas, sobretudo à menos privilegiadas. De igual maneira pede o envolvimento das empresas e dos meios de comunicação em vista do fortalecimento da formação e informação dos cidadãos em busca da efetivação da proposta educacional.

\section{Princípio 19}

É indispensável um esforço para a educação em questões ambientais, dirigida tanto às gerações jovens como aos adultos e que preste a devida atenção ao setor da população menos privilegiado, para fundamentar as bases de uma opinião pública bem informada, e de uma conduta dos indivíduos, das empresas e das coletividades inspirada no sentido de sua responsabilidade sobre a proteção e melhoramento do meio ambiente em toda sua dimensão humana. É igualmente essencial que os meios de comunicação de massas evitem contribuir para a deterioração do meio ambiente humano e, ao contrário, difundam informação de caráter educativo sobre a necessidade de protegê-lo e melhorá-lo, a fim de que o homem possa desenvolver-se em todos os aspectos (Estocolomo, 1972).

Embora a declaração ofereça princípios para a conservação a manutenção da vida no planeta, não houve unanimidade na recepção das orientações. O Brasil, foi um dos países a fazer oposição às diretrizes ambientais discutidas e apresentadas na Conferência. Na visão dos representantes do país era necessário desenvolver-se a qualquer custo. Segundo Duarte (2003, p. 17) apoiando-se no conceito de soberania absoluta, o país "apregoava ser necessário primeiro desenvolver-se, depois 'pagar a conta' dos danos ambientais, tal como haviam feito os países ricos".

Esse posicionamento em menor ou maior grau prevaleceu durante a preparação e desenvolvimento da Conferência. Analisando a postura do Brasil frente a essa realidade Corrêa do Lago (2007) afirma que:

alguns setores do ambientalismo brasileiro apontam para a atitude do Brasil em Estocolmo como um erro histórico: o Brasil ajudou a bloquear a agenda ambiental pelo temor à criação de instrumentos que legitimassem a diminuição da soberania, temor que só se justificava pelos abusos que eram cometidos pelo Governo, principalmente na área de direitos humanos (Corrêa Do Lago, 2007, p. 142).

Mesmo com os entraves encontrados no avanço das discussões e da tomada de atitudes em vista de resolver as problemáticas ambientais apresentadas pelas comissões de trabalho, ressalta-se as significativas contribuições da Conferência para o desenvolvimento e a visibilidade das discussões das questões ambientais. Corrêa do Lago aponta para as seguintes constatações

a maioria dos autores considera que as principais conquistas da Conferência de Estocolmo - independentemente dos êxitos ou derrotas de países específicos ou de grupos negociadores - teriam sido as seguintes: a entrada definitiva do tema ambiental na agenda multilateral e a determinação das prioridades das futuras negociações sobre meio ambiente; a criação do Programa das Nações Unidas para o Meio Ambiente - PNUMA (UNEP, pelas iniciais em inglês); o estímulo à criação de órgãos nacionais dedicados à questão de meio ambiente em dezenas de países que ainda não os tinham; o fortalecimento das organizações não-governamentais e a maior participação da sociedade civil nas questões ambientais ( Corrêa Do Lago, 2007, p. 48). 
É inegável a contribuição da Conferência de Estocolmo para a EA. Os anos que seguiram foram de criação de organismos em defesa do meio ambiente e fortalecimento das propostas de formação de professores para atuação na EA. Nesse caminho o Brasil, mesmo com o histórico contrário as reflexões da Conferência, cria no ano de 1973 a Secretaria Especial do Meio Ambiente - SEMA.

Dentre as principais incumbências destaca-se

Assessorar órgão e entidades incumbidas da conservação do meio ambiente, tendo em vista o uso racional dos recursos naturais;

Promover a elaboração e o estabelecimento de normas e padrões relativos à preservação do meio-ambiente, em especial dos recursos hídricos, que assegurem o bem-estar das populações e o seu desenvolvimento econômico e social;

Promover, em todos os níveis, a formação e treinamento de técnicos e especialistas em assuntos relativos à preservação do meio ambiente;

Promover, intensamente, através de programas em escala nacional, o esclarecimento e a educação do povo brasileiro para o uso adequado dos recursos naturais, tendo em vista a conservação do meio ambiente (Brasil, 1973).

A criação da SEMA representa um marco para o desenvolvimento da Política Ambiental no Brasil. A inserção da temática na legislação brasileira por meio desta secretaria manteve as portas para a participação do país em outras conferências. É importante notar que as funções atribuídas a esse órgão nacional indicam o caráter conservacionista e nacionalista que permeava a concepção de meio ambiente.

Os anos que seguiram foram marcados por três outros grandes eventos convocados pela Organização das Nações Unidas para a Educação, a Ciência e a Cultura - UNESCO e pela ONU.

O primeiro deles ficou conhecido como Seminário Internacional de Belgrado, realizado entre 13 e 22 de outubro de 1975 na capital da Sérvia, Iuguslávia. O evento "produziu a Carta de Belgrado e um Programa Internacional de Educação Ambiental (PIEA)" Moradillo; Oki (2004, p. 333)". O documento produzido e adotado pelos participantes oferece princípios e orientações para a criação do PIEA. Estruturalmente está organizado por áreas de atuação, tomando como base as problemáticas apresentadas pelas comissões durantes os eventos de preparação e a partir das sínteses discutidas no evento.

Através do PIEA inicia-se sistematicamente os trabalhos para conhecimento do que é produzido no campo das ações, métodos e materiais em EA, bem como estrutura e fortalecer o alcance, em vários segmentos da sociedade, enfatizando, sobretudo, os meios de educação formal e informal. Dentre os cinco grandes objetivos norteadores do programa, destaca-se,

Promover o intercâmbio de ideias, informações e experiências em Educação Ambiental entre as nações e regiões do mundo; fomentar o desenvolvimento e a coordenação de atividades de pesquisa que levem à melhor compreensão dos objetivos, conteúdos e métodos da Educação Ambiental; impulsionar o treinamento ou a atualização de pessoal chave para o desenvolvimento da Educação Ambiental, tal como professores, planejadores, pesquisadores e administradores educacionais (Belgrado, 1975).

Por meio desses objetivos foram encaminhadas as atividades setorizadas tendo como metas a organização sistemática e formação de redes de trabalho. Ademais, como encaminhamentos, o seminário lançou uma carta contextualizando a situação humana e ambiental do planeta e afirmando sobre a necessidade de desenvolver novos meios de resolução, de modo global, haja vista que "a forma anterior de tratar esses problemas crucias de maneira fragmentária tornou-se inviável" (Belgrado, 1975). Ao tratar sobre a forma fragmentária de pensar e resolver as situações, Morin (2003, p.14) reflete sobre a "sua insuficiência para tratar nossos problemas mais graves constitui um dos mais graves problemas que enfrentamos"

Para romper com a estrutura resolutiva fragmentária faz-se necessário uma reforma estrutural do modo de pensar e conceber a realidade. Uma reforma que contemple a sociedade no sentido amplo do termo e a escola, mas há que começar por 
algum lugar. Neste aspecto surge o questionamento "como reformar a escola sem reformar a sociedade, mas como reformar a sociedade sem reformar a escola?" (Morin, 2003, p.100)

Ao reconhecer a possibilidade de contribuição da educação para essa reforma, as reflexões produzidas no seminário põem sobre a EA a responsabilidade de promover essa reforma de modo permanente. Sobre isso o documento afirma que,

a reforma dos processos e sistemas educacionais é decisiva para a elaboração desta nova ética de desenvolvimento e ordem econômica mundial. Governos e formuladores de políticas podem ordenar mudanças e novas abordagens para o desenvolvimento, podem começar a melhorar as condições de convívio no mundo, mas tudo isso não passa de solução de curto prazo, a menos que a juventude mundial receba um novo tipo de educação. Isso implicará num novo e produtivo relacionamento entre estudantes e professores, entre escolas e comunidades, e entre o sistema educacional e a sociedade em geral (Belgrado, 1975).

Ao propor uma transformação do modelo de pensamento, desenvolvimento e educação pautado na formação de um novo modo de pensar, o seminário contribui para o fortalecimento de uma ética ambiental. Ao apontar como uma das soluções para a problemática ambiental, a formação das pessoas, sobretudo dos jovens, para uma nova ética, há a preocupação estrutura o desenvolvimento de soluções profundas e que ocorram de maneira individual e coletiva, com ou sem a proteção dos governantes.

Para isso há de se pensar que o modelo de escola amparado na reprodução do conhecimento não daria conta de atender a essa demanda. Assim, faz-se necessário um novo modelo de escola que ofereça outras concepções de ensino e aprendizagem e estabelece diferentes modos de relacionar-se com a sociedade. Neste ínterim, encontrar-se a dialética de reformar a escola para reformar a sociedade e reformar a sociedade para reformar a escola.

A Educação Ambiental recebeu como meta,

Desenvolver uma população mundial que esteja consciente e preocupada com o meio ambiente e com os problemas que lhe são associados, e que tenha conhecimento, habilidade, atitude, motivação e compromisso para trabalhar individual e coletivamente na busca de soluções para os problemas existentes e para a prevenção de novos (Belgrado, 1975) grifo nosso.

Em vista de detalhar as diretrizes centrais e distribuí-las de modo a facilitar a execução, foram elaborados 6 objetivos pautados em conscientização, conhecimento, atitudes, habilidades, capacidade de avaliação e participação.

No que diz respeito a conscientização a EA tem por objetivo "contribuir para que os indivíduos e grupos sociais adquiram consciência e sensibilidade em relação ao ambiente como um todo e os problemas a ele relacionados" (Belgrado, 1975).

O segundo objetivo proposto está direcionado ao conhecimento. Neste aspecto, a EA deve "propiciar aos indivíduos e grupos sociais uma compreensão básica sobre o ambiente como um todo e os problemas a ele relacionados, e sobre a presença e o papel de uma humanidade criticamente responsável" (Belgrado, 1975).

O conhecimento produzido pelas pessoas e o que até elas é levado deverá ser promotor de atitudes, neste aspecto a EA deve "possibilitar aos indivíduos e grupos sociais a aquisição de valores afetivos para com o ambiente e motivação para participar ativamente na sua proteção e melhoria" (Belgrado, 1975).

No que diz respeito as habilidades segundo os objetivos propostos a EA deve "propiciar aos indivíduos e aos grupos sociais condições de adquirirem as habilidades necessárias à solução dos problemas ambientais” (Belgrado, 1975).

Com o intuito de avaliar as ações que estão sendo desenvolvidas nos diversos segmentos da sociedade no que diz respeito a EA, cabe a ela "estimular os indivíduos e grupos sociais a avaliarem as providências relativas ao ambiente e os programas educativos, quanto aos fatores ecológicos, políticos, econômicos, estéticos e educacionais” (Belgrado, 1975). 
No que se refere a sensibilização em vista da participação a EA tem o papel de "contribuir com os indivíduos e grupos sociais no sentido de desenvolverem senso de responsabilidade e de urgência com relação aos problemas ambientais para assegurar a ação apropriada para solucioná-los” (Belgrado, 1975).

Na visão de Loureiro (2012),

o grande mérito desse seminário, apesar de resvalar em um certo economicismo liberal, foi reforçar a necessidade de uma nova ética global e ecológica, vinculada aos processos de erradicação de problemas como fome, miséria, analfabetismo, poluição, degradação dos bens naturais e exploração humana, por meio de um novo modelo de desenvolvimento e do entendimento de que tais problemas estão estruturalmente relacionados. Para isso, enfatizou-se a Educação ambiental como processo educativo amplo, formal ou não, abarcando as dimensões políticas, culturais e sociais, capaz de gerar novos valores, atitudes e habilidades compatíveis com a sustentabilidade da vida no planeta (Loureiro, 2012, p. 70).

A concepção de EA ambiental trazida pelo seminário, amplia a reflexão da conferência realizada em Estocolmo. O fortalecimento da necessidade de repensar um novo modo de relação entre os seres humanos e o planeta e entre os próprios seres humanos direciona os encaminhamentos para âmbitos mais amplos. Embora a visão de conservação dos recursos do planeta em favor da preservação da vida humana esteja como centro das questões, de forma incipiente, as questões que abordam a identidade do ser humano como pertencente ao planeta aparecem.

Outro dado importante a ser observado diz respeito a reflexão sobre o local e global. Há o fortalecimento da idéia de local e global, enfatizando que a responsabilidade com as questões ambientais diz respeito a todas as pessoas, em nível local e global, respeitando as particularidades da atuação de cada pessoa em sua realidade de vida e ambiente.

Após dois anos foi realizada em Tbilisi, Geórgia, entre 14 e 26 de outubro de 1977 a Conferência Intergovernamental sobre Educação Ambiental. Essa Conferência serviu de amadurecimentos aos passos significativos dados pela EA Belgrado. "Se a Conferência de Estocolmo foi considerada o marco da recomendação mundial sobre EA, a Conferência de Tbilisi constituiu-se no marco mais importante para a definição e evolução da sua institucionalização" (Ramos, 2001, p. 205).

Na visão de Oliveira (2013, p. 29) a Conferência se desenvolveu "apostando em objetivos, princípios e estratégias de implementação da prática de Educação Ambiental, no âmbito forma e informal”. As ações desencadeadas por esse evento tornaram-se fundamentais para o desenvolvimento do PIEA e, consequentemente, da EA. As propostas sugeridas em Estocolmo e iniciadas em Belgrado tomaram consistência em Tbilisi a partir de quarenta e uma recomendações a níveis mundial, nacional, regional e local. O plano oferecido pela Conferência,

converteu-se em referência para os órgãos, pessoas e instituições responsáveis pela EA no âmbito regional, nacional e internacional, constituindo-se num texto técnico com as finalidades, objetivos, princípios orientadores e estratégias para o desenvolvimento da EA (Ramos, 2001, p. 205)

As recomendações apresentam as necessidades de atuação e propõem caminhos para solucioná-las. Ademais, orienta que a EA deve ser desenvolvida levando em consideração a realidade local e global, como também enfatizando o seu caráter interdisciplinar. Pois concebe que

a Educação Ambiental é o resultado de uma reorientação e articulação das diversas disciplinas e experiências educativas, que facilitam a percepção integrada do meio ambiente, tornando possível uma ação mais racional e capaz de responder às necessidades sociais (Tbilisi, 1977).

Por isso ela deve, 
criar vínculos mais estreitos entre os processos educativos e a realidade, estruturando suas atividades em torno dos problemas ambientais concretos que se apresentam às comunidades e enfocar sua análise através de uma perspectiva interdisciplinar e global que permita a compreensão desses problemas (Tbilisi, 1977).

Ainda nessa perspectiva, reforçando a necessidade de promoção contínua e interdisciplinar da EA a conferência aponta como um dos princípios diretores a necessidade de

constituir-se num processo contínuo e permanente, iniciando na pré-escola e continuando através de todas as fases do ensino formal e não-formal; empregar um enfoque interdisciplinar, aproveitando o conteúdo específico de cada disciplina, para que se adquira uma perspectiva global e equilibrada (Tbilisi, 1977).

Ao atribuir a EA espaço em toda a formação escolar, afirmando a continuidade desses processos no âmbito da educação formal e informal, a Conferência busca inserir todas as pessoas no processo de EA. Os governos, os organismos de comunicação, as instituições de ensino básico, as instituições formadoras de educadores, as ONGs, enfim, a atribuição da responsabilidade é de todos em suas realidades e possibilidades.

Outro ponto que merece destaque nas reflexões trazidas pela Conferência diz respeito ao caráter de totalidade dado a EA. Isso representa um alargamento na compreensão de meio ambiente e pessoa humana. Idéia de meio ambiente como aquele intocado pelo ser humano ou destruído por ele vai sendo superada ao perceber que se faz necessário "considerar o ambiente em sua totalidade, ou seja, em seus aspectos naturais e artificiais, tecnológicos e sociais (econômico, político, técnico, históricocultural, moral e estético) (Tbilisi, 1977)."

Na visão de Ramos (2001, p. 205) "nas recomendações de Tbilisi, a EA vincula-se à compreensão de três conceitos fundamentais: aquisição de novos conhecimentos e valores, novos padrões de conduta e a interdependência". Desde essa perspectiva é possível perceber que a EA nasce sistematicamente como um agente de transformação do modo de pensar a relação entre o ser humano e a natureza. Como dito, este evento é considerado um marco para a EA.

No que diz respeito a participação do Brasil nas discussões e no evento, encontra-se o registro seguinte:

E o Brasil, neste evento? Não esteve presente, pelo menos em caráter oficial. A justificativa é, no mínimo, curiosa: segundo Regina Gualda, que naquela época era a chefe da Divisão de Comunicação e Educação Ambiental da Secretaria Especial do Meio Ambiente do governo federal, nosso país não mantinha relações diplomáticas com o bloco soviético, o que impediu a participação (Brasil, 1998, p. 30).

A não participação do Brasil no evento não implicou que o país deixasse de realizar ações no campo da EA. Ao compreender que em Tbilisi foram aprofundados os acordos realizados em Belgrado, em solo brasileiro era constituído pela Secretaria Especial de Meio Ambiente - SEMA um grupo de trabalho para a elaboração de um documento para mapear e contextualizar, bem como definir o papel da EA no Brasil.

A comissão apresentou um documento fundamentado nas diretrizes de formação da percepção, valores, habilidades e atitudes a serem desenvolvidas nos $1^{\circ}$ e $2^{\circ}$ graus (Ensino Fundamental e Médio), no ensino superior e na pós graduação em nível de mestrado e doutorado.

As recomendações foram elaboradas "visando auxiliar na remoção das dificuldades que se fazem sentir, e a propiciar o mais adequado desenvolvimento de ações na área da Educação Ambiental" (Brasil, 1977). No campo administrativo foram elaboradas seis recomendações, das quais destacam-se,

Fomentar, através principalmente da Universidade e do Conselho Nacional de Desenvolvimento Científico e Tecnológico $(\mathrm{CNPq})$, a formação e a utilização racional de tecnologia nacional de controle do meio ambiente; observar na elaboração e na atualização das propostas curriculares dos níveis de ensino, os objetivos da Educação Ambiental (Brasil, 1977). 
No campo da formação de recursos humanos também foram elaboradas seis recomendações das evidenciam-se,

incluir nos currículos dos cursos de formação de professores, em todos os níveis, a disciplina Ciências do Ambiente visando atender às características da Educação Ambiental; Promover a atualização dos professores em serviço através de cursos, seminários programas especiais de treinamento encontros etc., no sentido de oferecer lhes instrumentos para aplicação dos conteúdos, métodos e objetivos da Educação Ambiental (Brasil, 1977).

O terceiro grupo, formado por duas recomendações foi destinado ao processo de elaboração de materiais de apoio para o desenvolvimento das práticas em EA.

Incrementar a elaboração de material de apoio (impressos, filmes, audiovisuais, cartazes, manuais para professores e alunos, diapositivos etc.) para a Educação Ambiental, adaptado às diferentes realidades do País. Esse material é indispensável para que os educadores possam por em prática programas de Educação Ambiental (Brasil, 1977).

Essas recomendações ganharam maior visibilidade a partir da promulgação da Lei 6938/81 de 31 de agosto de 1981 pela qual foi estabelecida a Política Nacional de Meio Ambiente - PNMA, criado o Sistema Nacional do Meio Ambiente SISNAMA e o Conselho Nacional de Meio Ambiente - CONAMA.

A Política Nacional de Meio Ambiente, traz em seu rol a inserção da EA em todos os níveis de ensino, afirmando a importância e a valorização da construção do conhecimento tendo em vista melhoria da qualidade de vida e conservação do meio ambiente.

Art. $2^{\circ}$. A Política Nacional do Meio Ambiente tem por objetivo a preservação, melhoria e recuperação da qualidade ambiental propícia à vida, visando assegurar, no País, condições ao desenvolvimento socioeconômico, aos interesses da segurança nacional e à proteção da dignidade da vida humana, atendidos os seguintes princípios: X - educação ambiental a todos os níveis do ensino, inclusive a educação da comunidade, objetivando capacitá-la para participação ativa na defesa do meio ambiente.

Essa foi mais uma importante conquista tendo em vista a afirmação do lugar da EA na formação do ser humano. Ainda sobre esse lugar, é válido destacar a sua abrangência e finalidade. Ao inserir a comunidade no processo de preservação do meio ambiente e melhoria da qualidade de vida, a responsabilidade se expande para além dos poderes públicos e privados.

Outro evento de grande contribuição para o amadurecimento da EA ocorreu em Moscou em 1987. Em vista da promoção da avaliação de uma década da Conferência realizada em Tbilisi a UNESCO promoveu o Congresso Internacional em Educação e Formação Ambiental. No evento foram "analisadas as conquistas e dificuldades na área de EA desde a conferência de Tbilisi e discutido uma estratégia internacional de ação em educação e formação ambientais para a década de 90” (Souza \& Benevides, 2005, p. 533).

Por meio das reflexões dos processos ocorridos no decênio, chegou-se a percepção de que a EA deveria estabelecer como pilares a conscientização, a formação por meio da transmissão de informações, a preparação e desenvolvimento de hábitos e habilidades para a tomada de decisões. Na visão de Moradillo e Oki ( 2004) esse Congresso

destacou-se das demais por criar um quadro teórico-metodológico para a concretização da Educação Ambiental, sugerindo uma reorientação do processo educacional. Entre os objetivos dessa conferência estava um plano de ação para a implementação da Educação (Moradillo \& Oki, 2004, p. 333).

Ao propor essa avaliação as comissões fazem dois movimentos importantes para a reflexão e a consolidação da EA. Ao olhar para traz faz uma análise das dificuldades encontradas e dos avanços realizados na última década, e com o plano de ação, reforça a necessidade de melhoria, bem como assume diretrizes mais claras, a partir do caminho já trilhado. 
No cenário brasileiro, ocorria a reafirmação da necessidade de desenvolvimento da EA nos diversos níveis de ensino e de maneira interdisciplinar por meio do Parecer $n^{\circ} 226 / 87$.

Nele, ficou enfatizada a urgência da introdução da Educação Ambiental, propondo-se que fosse iniciada "a partir da escola, numa abordagem interdisciplinar, levando à população posicionamento em relação a fenômenos ou circunstâncias do ambiente". Além disso, o parecer sugeriu a criação de Centros de Educação Ambiental nos Estados, para atuarem como pólos irradiadores (Brasil, 1998a).

As concepções sobre a necessidade de envolvimento de todos os setores da sociedade com a EA apresentadas nos eventos que discutiram a sua implementação e consolidação aparecem nesse parecer com a criação dos Centros de EA com o intuído de formar células de reflexão em vista de abranger todo o território nacional.

O ano que segue, 1988 representou para as brasileiros um marco no processo de redemocratização do país. Nesse ano foi promulgada a Constituição Federal - CF de 1988.

Art. 225. Todos têm direito ao meio ambiente ecologicamente equilibrado, bem de uso comum do povo e essencial à sadia qualidade de vida, impondo-se ao poder público e à coletividade o dever de defendê-lo e preservá-lo para as presentes e futuras gerações. $\$ 1^{\circ}$ - Para assegurar a efetividade desse direito, incumbe ao poder público:VI - promover a educação ambiental em todos os níveis de ensino e a conscientização pública para a preservação do meio ambiente (Brasil, 1988).

A Carta Magna do país reconhece a necessidade de garantir aos cidadãos brasileiros um meio ambiente ecologicamente equilibrado. Ademais, enfatiza a função do Estado em promover essa garantia, tendo com um dos meios a EA. Ao mencioná-la como instrumento de conscientização e formação em prol da promoção do meio ambiente e da vida humana a Constituição Federal alinha-se aos documentos internacionais que orientam e regulamentam a EA.

Constituição Federal, com seu Capítulo do Meio Ambiente que, entre outros avanços na área ambiental, tornou a educação ambiental obrigatória em todos níveis de ensino, sem, no entanto, tratá-la como uma disciplina. Esta era a proposta do grupo majoritário, do qual participou o professor Almeida Júnior, sendo que a redação final ficou de acordo com as definições internacionais de Tbilisi, reafirmadas no encontro de Moscou (Brasil, 1998).

Ao se posicionar por meio da CF de 1988 em consonância com as propostas apresentadas em nível mundial, o governo brasileiro ganhou visibilidade no cenário, sobretudo pelas ações que foram tomadas em decorrência da Lei Magna do país. No ano de 1989, ocorreu a criação do Fundo Nacional de Meio Ambiente - FNMA em vista de promover o apoio aos projetos na área da EA. As ações foram se desdobrando de acordo com as áreas de atuação e competência.

Em fevereiro de 1989, o Governo Federal criou o Instituto Brasileiro do Meio Ambiente e dos Recursos Naturais Renováveis (IBAMA), as agências federais na área de pesca, desenvolvimento florestal e borracha. Neste novo órgão, a EA tornar-se-ia uma Divisão do Departamento de Divulgação Técnico, Científica e Educação Ambiental, pertencente à Diretoria de Incentivo à Pesquisa e Divulgação (Brasil, 1998a).

Com a reforma ocorrida em decorrência da $\mathrm{CF}$, os Municípios e Estados tiveram que promover mudanças em suas Leis Orgânicas e Constituições Estaduais. Com isso muitas "Constituições estaduais e Leis Orgânicas Municipais repetiram as propostas da Constituição Federal, incluindo um capítulo do meio ambiente, com referências à EA" (Brasil, 1998).

Voltando ao cenário mundial, ocorre em Jomtien- Tailândia, entre os dias 5 a 9 de março de 1990 a Conferência Mundial sobre Educação para Todos Satisfação das Necessidades Básicas de Aprendizagem. A Conferência traz à baila de discussão as dificuldades do cenário mundial que interferem de maneira direta e indiretamente na promoção da educação. Segundo a declaração aprovada no evento, as condicionantes da fome, guerra, violência e economia são "problemas atropelam os esforços envidados no sentido de satisfazer as necessidades básicas de aprendizagem, enquanto a falta de educação básica 
para significativas parcelas da população impede que a sociedade enfrente esses problemas com vigor e determinação" (Jomtien, 1990).

Ao evidenciar as necessidades de promover a educação para transformar a sociedade incentivar a sociedade a acreditar na educação como resolução dos problemas sociais, políticos e econômicos a conferência põe em discussão o acesso à educação para todos. Pois, sabe-se "que a educação, embora não seja condição suficiente, é de importância fundamental para o progresso pessoal e social" (Jomtien, 1990).

As discussões dessa conferência, diferentemente das demais, não abordaram especificamente da EA, mas enfatizaram a necessidade de promoção da educação como meio de transformação social e conservação do meio ambiente. Ademais, ressaltou o direito fundamental de todo ser humano a ter acesso à educação básica.

Para a EA brasileira o ano de 1991 foi marcado pela criação de espaços, em vésperas da Conferência das Nações Unidas Sobre o Meio Ambiente e Desenvolvimento (Rio/1992), foi formulada e assinada pelo Ministério da Educação e Cultura - MEC a Portaria n ${ }^{\circ}$ 678/91, pela qual ficou estabelecido que todos os sistemas e instituições de ensino do país deveriam adequar seus currículos de modo a contemplar a Educação Ambiental.

Os sistemas de ensino em todas as instâncias, níveis e modalidades contemplem, nos seus respectivos currículos, entre outros, os seguintes temas/conteúdos referentes 1: a) Prevenção do uso indevido de substâncias psicoativas; b) Educação ambiental; c) Educação no trânsito; d) Educação do consumidor; e) Prevenção das DST/AIDS; f) Prevenção de acidente do trabalho; g) Defesa civil; h) Relação contribuinte/Estado; e, i) Educação em saúde (Brasil, 1991).

No tocante a inserção da EA e de outros temas elencados na Portaria, o MEC apresenta a preocupação e alerta para o risco de que sejam postos no currículo das instituições sem levar em consideração as características regionais e locais bem como a idade dos alunos, níveis de ensino entre outros. Nessa linha, há ênfase no cuidado que deve ser tomado para que não haja a supressão de outros temas em detrimento desses que são apresentados.

2 - O aprofundamento e a exploração desses temas/conteúdos não significam a inclusão de matérias ou disciplinas especificas, mas permearão todo o currículo nos diferentes níveis e modalidades de ensino, ajustando-se, por isso, à idade do estudante e ao nível de aprendizado; 2.1 - Os conteúdos não devem ser simplesmente adicionados aos já existentes ou substituir outros temas considerados defasados, mas analisados o selecionados em função da realidade, buscando atender as exigências do cotidiano em consonância com o objetivo maior da educação (Brasil, 1991).

Na proposta oferecida pela Portaria, evidencia-se a transversalidade e interdisciplinaridade da EA. Ressalta-se que nos documentos que a orientam e regulamentam essa preocupação e discussão está sempre presente. O propósito de promover reflexões que estejam presentes em todas as áreas do conhecimento reflete a sua abrangência e importância. A EA não veio para abolir os conteúdos específicos das áreas do conhecimento e das disciplinas, na realidade, ela deve ser discutida e desenvolvida a partir desses conteúdos já postos, mas que a EA esteja presente de forma contextualizada visto, a sua importância de forma transversal e interdisciplinar. Embora esses aspectos apareçam enfaticamente, a redação da Portaria os põe claramente para que na aplicabilidade não haja falta de entendimento do que se espera da implementação da EA.

Em âmbito nacional e internacional o ano de 1992 representou um momento de implementação de organismos no Brasil e de discussão dos rumos do cuidado com o meio ambiente em nível mundial

No cenário interno foi criado o Ministério do Meio Ambiente com a missão de formular e implementar políticas públicas no território nacional conjuntamente com a sociedade em vista da promoção do desenvolvimento sustentável, e "foram instituídos Núcleos de Educação Ambiental em todos os Estados Brasileiros, como forma de desenvolver políticas públicas" (Oliveira, 2013, p. 35).

Em nível internacional ocorreu no ano de 1992 na cidade do Rio de Janeiro - Brasil a Conferência das Nações Unidas sobre o Meio Ambiente. 
Os números da Conferência do Rio são eloquentes: o maior evento organizado pelas Nações Unidas até aquele momento, a Conferência reuniu delegações de 172 países e trouxe ao Rio de Janeiro 108 Chefes de Estado ou de Governo (Corrêa Do Lago, 2007, p. 52).

A massiva participação na Conferência revela que a temática ambiental ganhou respaldo para além da academia e da preocupação de uns poucos grupos ou países. Aquilo que era considerado por alguns países em desenvolvimento, como o Brasil, como uma preocupação secundária se torna epicentro das discussões desenvolvimentistas e comerciais. O clamor das Conferências que antecederam a ocorrida em 1992 foi ouvido por muitos governantes, cientistas, estudiosos e ativistas, resultando no grande evento Rio-92

O enriquecimento do debate em torno da questão do meio ambiente nas duas décadas entre Estocolmo e o Rio de Janeiro deu-se em todos os níveis - governamental, não-governamental, empresarial, acadêmico e científico (Corrêa Do Lago, 2007, p. 55).

É importante destacar que todo esse envolvimento com a causa ambiental não era de todo uma preocupação com o meio ambiente. Havia os interesses comerciais e de desenvolvimento econômico. Os países do sul desejam retomar a agenda comercial com os países do norte e, percebem a oportunidade de fazê-lo por meio da propaganda ambiental. Ao aderir aos acordos propostos no evento, os países se comprometiam com o desenvolvimento de estratégias que fossem viáveis economicamente e que resguardassem de alguma maneira o meio ambiente. Neste sentido, a Conferência se desenvolve

com o objetivo central de estabelecer acordos, estratégias globais e internacionais, partindo do princípio de que se respeitem "os interesses de todos e se proteja a integridade do sistema ambiental e o desenvolvimento mundial (Ramos, 2001, p. 205).

Embora as questões políticas apareçam com destaque nas discussões, é válido destacar que paralelamente ocorreram movimentações em vista da promoção de ações que viabilizassem a formação dos indivíduos para a conservação do meio ambiente no que tange a EA destaca-se o capítulo 36 da Agenda 21, dedicado a promoção do ensino, da conscientização e do treinamento. "Com efeito, apenas uma única menção foi feita à EA em todo o texto do Capítulo 36" (Barbieri; Silva, 2011, p. 58). Em paralelo ao grande evento ocorreu um encontro com profissionais da EA em vista de promover reflexões exclusivas para esse segmento. Neste aspecto aponta-se que

O Ministério da Educação e Desportos (MEC) organizou um Encontro onde foi aprovado o documento "Carta Brasileira para a Educação Ambiental" que enfoca o papel do estado em relação à Educação Ambiental e sua implementação em todos os níveis de ensino (Moradillo; Oki, 2004, p. 333).

A carta elaborada pelos participantes desse evento aponta para as necessidades de definir procedimentos em vista do diagnóstico da realidade ambiental brasileira; estabelecer o marco fundamental para a implantação da EA no ensino superior, levando em consideração a importância dela na transformação social, bem como insiste que a EA seja oferecida com base na multi, inter e transdisciplinaridade.

A Carta Brasileira para Educação Ambiental, que, entre outras coisas, reconhece ser a educação ambiental um dos instrumentos mais importantes para viabilizar a sustentabilidade como estratégia de sobrevivência do planeta e, consequentemente, de melhoria da qualidade de vida humana (Brasil, 2005, p. 24).

A carta em pauta aponta para a falta comprometimento do Poder público com a causa, e de igual maneira ressalta a importância da EA como instrumento de transformação da realidade. No que diz respeito a organização nacional da EA, no ano de 1994 em parceria com os Ministérios da Educação, Meio Ambiente, Ciência e Tecnologia, e Comunicação, o Programa Nacional de Educação Ambiental - PRONEA com o objetivo de promover a efetivação da EA, sobretudo no âmbito formal. 
O Programa previu três componentes: “(a) capacitação de gestores e educadores, (b) desenvolvimento de ações educativas, e (c) desenvolvimento de instrumentos e metodologias" (Brasil, 2005, p. 25).

Em 1997 ocorreu em Tessalônica - Grécia a Conferência Internacional sobre o Meio Ambiente e Sociedade: Educação e consciência pública para a sustentabilidade. Dentre as várias discussões realizadas chegaram-se as conclusões de que desde a realização do último evento Rio-92 no Brasil as ações não alcançaram as metas propostas, prejudicando o progresso da EA e da sustentabilidade. Ademais, evidenciou-se a pobreza como um dos empecilhos para a educação e a redução da degradação ambiental, por isso a necessidade de juntar esforços de todos os setores possíveis em prol da causa.

A Declaração de Tessalônica considerou válidos os planos e as recomendações das conferências de Belgrado, Tbilisi, Moscou e outras relacionadas com a EA, mas reconheceu que não foram completamente explorados, e os resultados alcançados foram insuficientes (Barbieri \& Silva, 2011, p. 60).

Como reflexão do que foi constatado pela Conferência de Tessalônica, ressalta-se que no ano de 1996 foi lançado no Brasil a Lei de Diretrizes e Bases da Educação Nacional, Lei 9694/96 na qual não faz nenhuma menção direta a EA.

Somente em 1997 com o Lançamento dos Parâmetros Curriculares Nacionais - PCN's foi proposto o tema Meio Ambiente a ser trabalhado de forma transversal nos 4 ciclos do ensino fundamental.

Os PCN's aparecem como subsídio para direcionar a instituição de ensino na elaboração da proposta de ensino e aprendizagem a partir de temáticas que devem ser desenvolvidas levando em consideração a realidade dos alunos e o contexto escolar.

Nesse mesmo ano de 1997 foi realizada em Brasília, DF a $1^{\text {a }}$ Conferência Nacional de Educação Ambiental com o propósito de discutir os rumos para a EA no país. Esse evento foi promotor da Declaração de Brasília para a Educação Ambiental em que teve como resultado a Carta denominada de "Carta de Brasília para a Educação Ambiental", na qual propõe a discussão em cinco áreas temáticas.

Educação ambiental e as vertentes do desenvolvimento sustentável. Educação ambiental formal: papel, desafios, metodologias e capacitação. Educação no processo de gestão ambiental: metodologia e capacitação. Educação ambiental e as políticas públicas: PRONEA, políticas de recursos hídricos, urbanas, agricultura, ciência e tecnologia. Educação ambiental, ética, formação da cidadania, educação, comunicação e informação da sociedade (Brasil, 2005, p. 27).

Em virtude do campo de estudos dessa pesquisa esse documento merece destaque e, sobretudo, a temática da EA formal, papel, desafios e metodologias, haja vista que o tópico discute as dificuldades encontradas para implementação da EA no currículo escolar. As causas apresentadas giram em torno da fragmentação do ensino que amparado numa lógica positivista e tecnicista dificultam o lançamento de um olhar holístico sobre a realidade; da constatação de que as políticas públicas não caminham no mesmo ritmo que as urgências sociopolíticas, assim como a ausência de pesquisas na área e precária formação dos profissionais da educação.

Ao se constatar que a transmissão dos valores pro - sustentabilidade exige a ruptura de paradigmas positivistas, a Declaração de Brasília acena para o caráter holístico da educação ambiental, avessa, portanto, à fragmentação temática adotada por modelos pedagógicos tradicionais (Brasil, 1997).

Esse aceno a necessidade de buscar novos meios de conceber a EA está em vista de preencher as lacunas que vêm sendo deixadas na implementação dessa educação. Além disso, é uma abertura a compreensão de que a realidade da vida se dá na complexidade das relações e, no campo educacional não seria diferente.

Dando sequência aos trabalhos em prol da sistematização e consolidação da EA no Brasil em 1998 foram instituídas pelo MEC as Diretrizes Curriculares Nacionais para o Ensino Fundamental, por meio da Resolução ${ }^{\circ} 2$ que de 7 de abril de 
1998, que institui as Diretrizes Curriculares Nacionais para o Ensino Fundamental. Segundo elas, torna-se obrigatório a promoção do acesso para todos os alunos temáticas que contemplem "a vida cidadã através da articulação entre vários dos seus aspectos como: a saúde, a sexualidade, a vida familiar e social, o meio ambiente, o trabalho, a ciência e a tecnologia, a cultura, as linguagens" (Brasil, 1998b).

No ano seguindo, em 1999 foi aprovada a Lei Federal 9.795/1999 que com o intuito de dispor sobre a EA e instituir a Política Nacional de Educação Ambiental - PNEA. Essa disposição sobre a compreensão conceitual do que é a Educação Ambiental, os seus princípios básicos e norteadores e a quem ela se destina foi e continua sendo fundamental para, ainda que minimamente, possa se assegurar que ela seja desenvolvida por temáticas semelhantes.

Como se tem demonstrado até o momento os caminhos percorridos pela EA ao longo de seu trajeto de início, amadurecimento e desenvolvimento, facilitou que surgissem diversas concepções sobre a finalidade da EA e, consequentemente, de práticas pedagógicas para seu desenvolvimento no contexto escolar. Assim, a Lei 9.795/1999 em pauta apregoa que,

Art. 1ํㅡㄹ Entendem-se por educação ambiental os processos por meio dos quais o indivíduo e a coletividade constroem valores sociais, conhecimentos, habilidades, atitudes e competências voltadas para a conservação do meio ambiente, bem de uso comum do povo, essencial à sadia qualidade de vida e sua sustentabilidade (Brasil, 1999).

É importante destacar que as concepções de promover por meio da EA valores, conhecimentos, habilidades, atitudes e competências estão presentes em maior ou menor grau nos documentos que antecedem essas Leis, seja nível internacional ou nacional. O que vem se colocando em debates são as formas de abordagem e de como desenvolver e implementar essas temáticas em nível governamental e educacional.

Outro ponto que a Lei vem reafirmar o que já havia sido apresentado anteriormente é o caráter permanente da EA em todos os níveis de ensino e de forma articulada com todas as disciplinas existentes no currículo escolar. Dada a amplitude, importância e necessidade da EA para a transformação da realidade social, deve ser pensada e desenvolvida em caráter formal e não formal da educação. "Art. 2º A educação ambiental é um componente essencial e permanente da educação nacional, devendo estar presente, de forma articulada, em todos os níveis e modalidades do processo educativo, em caráter formal e nãoformal" (Brasil, 1999).

Como dito, dada a amplitude da temática ambiental e dos diversos modos de desenvolvê-la nos diversos níveis de ensino, falando da educação formal e, se estendendo para o âmbito da educação não formal e informal, fez-se necessário estabelecer os princípios básicos pelos quais a EA deve ser desenvolvida no país. Assim, sugere-se que tenha como princípios básicos,

I - o enfoque humanista, holístico, democrático e participativo;

II - a concepção do meio ambiente em sua totalidade, considerando a interdependência entre o meio natural, o socioeconômico e o cultural, sob o enfoque da sustentabilidade;

III - o pluralismo de ideias e concepções pedagógicas, na perspectiva da Inter, multi e transdisciplinaridade;

IV - a vinculação entre a ética, a educação, o trabalho e as práticas sociais;

$\mathrm{V}$ - a garantia de continuidade e permanência do processo educativo;

VI - a permanente avaliação crítica do processo educativo;

VII - a abordagem articulada das questões ambientais locais, regionais, nacionais e globais;

VIII - o reconhecimento e o respeito à pluralidade e à diversidade individual e cultural (Brasil, 1999).

Reafirmando as propostas da carta para a EA escrita na $1^{\text {a }}$ Conferência de Educação Ambiental no Brasil em 1997, a Política Nacional de Educação Ambiental Lei no $9795 / 99$ institui as diretrizes para o desenvolvimento da EA com valores e enfoque humanista, holístico, democrático e participativo visando proporcionar a interdisciplinaridade, a multidisciplinaridade e a transdisciplinaridade. Ademais reforça a necessidade de desenvolver a EA na concepção do meio ambiente em sua 
totalidade, considerando a interdependência entre o meio natural, o socioeconômico e o cultural, sob o enfoque da sustentabilidade.

No ano de 2002, ocorreu em Joanesburgo na África do Sul entre os dias 26 de agosto e 04 de setembro a Cúpula Mundial sobre o Desenvolvimento Sustentável. O evento foi organizado pela ONU em vista de discutir as questões ambientais e avaliar o progresso e efetivação do que fora proposto na Rio-92. Esse segundo objetivo acabou por batizar a cúpula como Rio+10, ou seja, 10 anos após a conferência ocorrida no Rio de Janeiro - Brasil em 1992.

As discussões e relatórios constataram que, embora tenham ocorrido esforços, as metas não foram alcançadas, "mais uma vez constatou-se a necessidade de todas as nações se engajarem na tarefa de preservação do nosso planeta, assumindo as responsabilidades que cabem a cada uma delas, visando o cumprimento efetivo de compromissos já assumidos" (Moradillo; Oki, 2004, p. 333).

No caso particular do Brasil, evidencia-se um avanço na participação e preocupação com as questões ambientas desde Estocolmo. Se outrora o país apresentava-se como um entrave para as discussões, no contexto de Joanesburgo, ele aparece com um dos que desponta na efetivação das ações propostas.

O final da Cúpula, embora reconhecendo certa frustração perante os resultados obtidos, a Delegação brasileira registrava como êxito o endosso de princípios firmados na Conferência do Rio, como atesta o da responsabilidade comum, mas diferenciada para os países desenvolvidos e em desenvolvimento (França, 2010, p. 25).

Como demonstrado através das ações promovidas pelo governo brasileiro, houve uma preocupação com a efetivação das propostas assumidas para o desenvolvimento sustentável e incorporação da EA no campo da educação formal e informal. É importante destacar o momento histórico vivido pelo país desde Estocolmo com a mudança de regime de governo ditatorial e a redemocratização. Esse processo desencadeou o projeto de retirar da nação o status de vilão ambiental.

A cúpula reconhece que os avanços a nível mundial não ocorreram como o esperado e, por isso, o documento final apregoa sobre necessidade de continuar a somar esforços em prol do desenvolvimento sustentável. É válido destacar que nessa Conferência as questões sobre a erradicação da pobreza ganham força nas discussões. Como síntese das metas e desafio a serem vencidos destaca-se

trabalharemos juntos para nos ajudar mutuamente a ter acesso a recursos financeiros e aos benefícios da abertura de mercados, assegurar a capacitação e usar tecnologia moderna em prol do desenvolvimento, e assegurar que haja transferência de tecnologia, desenvolvimento de recursos humanos, educação e treinamento para banir para sempre o subdesenvolvimento (Joanesburgo, 2002).

O papel atribuído a educação como meio para banir para sempre o subdesenvolvimento é fator relevante para importância que foi sendo dada paulatinamente nas Conferências. Embora o trecho que trata sobre a participação da educação nessa erradicação não traga o adjetivo "ambiental" em sentido contextual aplica-se a ela também.

Em âmbito nacional em 2004 foi reorganizado o Programa Nacional de Educação Ambiental - PNEA, visando assegurar a EA o caráter prioritário, de permanente atenção e desenvolvimento no país nos âmbitos formal e informal na perspectiva da sustentabilidade. A ênfase dada pelo Programa amplia a reflexão para a interação e integração de múltiplas dimensões ambiental, levando em consideração as perspectivas ecológicas, social, ética, cultural, econômica, espacial e política. Para desenvolver esse percurso, o Programa propõe as seguintes diretrizes de trabalho:

1 - Transversalidade e Interdisciplinaridade; 2 - Descentralização Espacial e Institucional; 3 - Sustentabilidade Socioambiental; 4 - Democracia e Participação Social; 5 - Aperfeiçoamento e Fortalecimento dos Sistemas de Ensino, Meio Ambiente e outros que tenham interface com a educação ambiental (Brasil, 2005, p. 33). 
Nota-se que o caráter transversal e interdisciplinar aparece como característica primordial para a EA, além disso, levase em consideração a realidade socioambiental, saindo de uma visão unilateral de meio ambiente e reforçando o conjunto dos elementos que o compõe, como a garantia de direitos, a defesa da democracia e a participação dos indivíduos nos diversos segmentos da sociedade.

O ano de 2012 representa para a EA um episódio particular, primeiro pela Conferência das Nações Unidas sobre Desenvolvimento Sustentável, denominada de Rio+20 em menção a Conferência ocorrida no Rio de Janeiro em 1992.

Os principais eixos de discussão estiveram baseados na economia verde no contexto do desenvolvimento sustentável e da erradicação da pobreza e a estrutura institucional para o desenvolvimento sustentável. Em relação ao documento final Ferrari $(2014$, p.151) aponta que ele "reafirma, recorda e reitera conteúdos de documentos e acordos internacionais já referendados".

Este evento, embora não tenha o objetivo de tratar especificamente da EA, aborda, dentre vários assuntos, a importância da educação como meio de transformação social. Ao levantar esse discurso enfático sobre a educação, abre as portas para a ampla reflexão dos objetivos que se deseja alcançar por meio dela.

O texto reafirma o compromisso de todos os países signatários com a educação, focando no comprometimento de reforçar a cooperação internacional para "alcançar o acesso universal à educação primária, especialmente para os países em desenvolvimento". Complementa, ainda, que a educação de qualidade em todos os níveis é uma "condição essencial para alcançar o desenvolvimento sustentável, a erradicação da pobreza, a igualdade de gênero" (Ferrari, 2014, p. 162).

Nessa perspectiva, ao abordar as questões ambientais de forma ampla, trazendo à baila situações como a erradicação da pobreza e da fome, esses assuntos entram no rol de discussões dos organismos que discutem os rumos das nações e, consequentemente, chegam ao planejamento escolar.

O segundo dado importante para a EA no Brasil diz respeito ao lançamento da Resolução no 02, de 15 de junho de 2012, a qual estabelece as Diretrizes Curriculares Nacionais para a Educação Ambiental - DCNEA, apresentando-se como referência para a promoção da Educação Ambiental em todos os níveis e modalidades do Ensino Formal no Brasil.

As Diretrizes possuem os objetivos de estimular a reflexão crítica em todos os níveis de ensino, orientar os cursos superiores e sistemas educativos na formulação, execução e avaliação de seus projetos institucionais e pedagógicos. Para isso destaca que

A Educação Ambiental é uma dimensão da educação, é atividade intencional da prática social, que deve imprimir ao desenvolvimento individual um caráter social em sua relação com a natureza e com os outros seres humanos, visando potencializar essa atividade humana com a finalidade de torná-la plena de prática social e de ética ambiental (Brasil, 2012).

A esse respeito ressalta-se o comprometimento social da educação e, especificamente da EA, devendo ser desenvolvida em vista do fortalecimento do senso crítico e participativo dos estudantes. De igual maneira enfatiza-se a EA como uma dimensão da educação, compreendendo como intrinsecamente ligadas, de modo que não seja confundida com uma nova modalidade de educação.

Tendo como característica a formação crítica, deve fomentar nos estudantes a responsabilidade cidadã e o comprometimento com a vida em sua plenitude com base na reciprocidade das relações humanas e dos seres humanos com o meio em que vivem e do qual são parte constituinte. A EA "não é atividade neutra, pois envolve valores, interesses, visões de mundo, e desse modo, deve assumir na prática educativa, de forma articulada e interdependente, as suas dimensões política e pedagógica" (Brasil, 2012). 
Partindo dessas concepções as Diretrizes apresentam seis princípios norteadores para as práticas em EA, dos quais destaca-se,

I - totalidade como categoria de análise fundamental em formação, análises, estudos e produção de conhecimento sobre o meio ambiente;

II - interdependência entre o meio natural, o socioeconômico e o cultural, sob o enfoque humanista, democrático e participativo;

III - pluralismo de ideias e concepções pedagógicas (Brasil, 2012).

Ao apresentar esses princípios as Diretrizes oferecem perspectivas para a realização da EA levando em consideração os aspectos totalizadores da vida, a compreensão de que os estudos e as práticas pedagógicas devem contemplar as dimensões econômicas, políticas, sociais, emocionais, étnicas, culturais, dentre outras, remete-se a promoção de uma educação abrangente em sua totalidade.

Ainda sobre isso, ressalta a necessidade de abarcar o pluralismo de ideias e concepções pedagógicas. Admitindo que haja espaço para as mais diversas concepções de EA e que podem ser desenvolvidas de inúmeras formas.

No ano de 2014, foi apresentada a proposta brasileira do Programa Nacional Escolas Sustentáveis (PNES), inspirada no modelo inglês Sustainable Schools, elaborada pela Coordenadoria Geral de Educação Ambiental do Ministério da Educação em parceria com as Universidades Federais do Mato Grosso - UFMT, Mato Grosso do Sul - UFMS e Ouro Preto - UFOP. Esta proposta fundamentou-se nos documentos nacionais entre eles a Resolução CNE/CP n. ${ }^{\circ}$ 02/2012 - Diretrizes Curriculares Nacionais para a Educação Ambiental e a Resolução n. ${ }^{\circ}$ 18/2013 - PDDE Escola Sustentável; Programa Nacional de Escolas Sustentáveis - PNES/2014 - Versão preliminar. Destaca-se nestes documentos, o papel da Educação Ambiental no estímulo à constituição de instituições de ensino como espaços educadores sustentáveis, por meio da articulação entre currículo, espaço físico/edificações, gestão e relações escola-comunidade (Brasil, 2012; Brasil, 2013; Brasil, 2014).

$\mathrm{O}$ avanço das ações e a emergência de novas perspectivas teórica e metodológicas no campo da EA, motivaram a elaboração de uma nova versão do ProNEA no ano de 2018. Este novo texto teve por objetivo a atualização dos marcos legais e normativos e a indicação de novos caminhos necessários frente aos desafios para reafirmar o compromisso e a participação no desenvolvimento da Educação Ambiental, com vista a ações promotoras da sustentabilidade no país. De certa forma, tal documento promoveu uma renovação nos coletivos de educadores ambientais, pois também denotava uma preocupação governamental com a formação da cidadania.

\section{Considerações Finais}

O presente artigo trouxe um panorama a partir de uma revisão analítica do processo de formulação, inserção e implementação bem como os processos de (re)construção das Políticas Públicas da EA no Brasil a partir dos eventos internacionais e nacionais. Os resultados visaram apresentar os principais eventos que marcam a história da Educação Ambiental como trazer as contribuições e objetivos de cada um deste para os avanços no campo da Educação Ambiental como dimensão da educação.

Em síntese organizamos esses dados no Quadro 02 com as suas características e contribuições a partir de cada evento e sua abrangência, como mostra-se a seguir.

\begin{tabular}{|l|l|l|}
\hline \multicolumn{1}{|c|}{ Acontecimento/ano } & \multicolumn{1}{|c|}{ Abrangência } & \multicolumn{1}{c|}{ Característica/contribuição } \\
\hline $\begin{array}{l}\text { Publicação da obra } \\
\text { "Primavera Silenciosa" } \\
\text { pela bióloga Rachel Carson }\end{array}$ & Internacional & $\begin{array}{l}\text { Oferece reflexões com tônica de alerta sobre o modo predatório da relação } \\
\text { estabelecida entre o ser humano e a natureza }\end{array}$ \\
\hline É utilizado pela primeira & Internacional & O termo foi proposto pelo filósofo e médico Alemão Albert Schwitzer. Durante a \\
\hline
\end{tabular}




\begin{tabular}{|c|c|c|}
\hline $\begin{array}{l}\text { vez o termo Educação } \\
\text { Ambiental (1965) }\end{array}$ & & Conferência em Educação realizada pela Universidade de Keele- Grã-Bretanha \\
\hline $\begin{array}{l}\text { Fundação do Clube de } \\
\text { Roma (1968) }\end{array}$ & Internacional & $\begin{array}{l}\text { Discute sobre as reservas naturais não renováveis e o crescimento populacional no } \\
\text { âmbito mundial }\end{array}$ \\
\hline $\begin{array}{l}\text { Divulgação do Relatório } \\
\text { do Grupo de Roma (1972) }\end{array}$ & Internacional & $\begin{array}{l}\text { Alerta sobre a necessidade de impor limites ao crescimento econômico e } \\
\text { populacional visto que esse modo de desenvolvimento não está compatível com as } \\
\text { reservas de recursos naturais }\end{array}$ \\
\hline $\begin{array}{l}\text { Conferência de Estocolmo } \\
\text { (1972) }\end{array}$ & Internacional & $\begin{array}{l}\text { Marco inicial para conscientizar a sociedade e atender necessidades sociais sem } \\
\text { comprometer gerações futuras e lançamento da Declaração sobre o Ambiente } \\
\text { Humano }\end{array}$ \\
\hline $\begin{array}{l}\text { Criação da Secretaria } \\
\text { Especial de Meio } \\
\text { Ambiente-SEMA (1973) }\end{array}$ & Nacional & $\begin{array}{l}\text { Acompanha, assessora e promove ações em vista da conservação do meio } \\
\text { ambiente em território nacional }\end{array}$ \\
\hline $\begin{array}{l}\text { Conferência de Belgrado } \\
(1975)\end{array}$ & Internacional & $\begin{array}{l}\text { Surgimento de novos conceitos, habilidades, valores e atitudes visando a melhoria } \\
\text { da qualidade ambiental }\end{array}$ \\
\hline $\begin{array}{l}\text { Programa Internacional de } \\
\text { Educação Ambiental-PIEA } \\
\text { (1975) }\end{array}$ & Internacional & $\begin{array}{l}\text { Promove ações em vista da sistematização das pesquisas e trabalhos realizados em } \\
\text { EA, bem como a definição e compreenão dos seus objetivos }\end{array}$ \\
\hline $\begin{array}{l}\text { Conferência de Tbilisi } \\
\text { (1977) }\end{array}$ & Internacional & $\begin{array}{l}\text { Definição, institucionalização e regulamentação da EA, apostando em objetivos, } \\
\text { princípios e estratégias de implementação da sua prática no âmbito forma e } \\
\text { informal }\end{array}$ \\
\hline $\begin{array}{l}\text { Documento diretor sobre } \\
\text { as diretrizes da EA no } \\
\text { Brasil (1977) }\end{array}$ & Nacional & $\begin{array}{l}\text { Por meio de uma comissão instituída pela SEMA apresenta-se um documento } \\
\text { diretor baseado em percepção, valores, habilidades e atitudes a serem } \\
\text { desenvolvidas em todos os níveis de ensino }\end{array}$ \\
\hline $\begin{array}{l}\text { Lei 6938/81 Estabelece a } \\
\text { Política Nacional de Meio } \\
\text { Ambiente-PNMA (1981) }\end{array}$ & Nacional & $\begin{array}{l}\text { Inserção da EA em todos os níveis de ensino, afirmando a importância e a } \\
\text { valorização da construção do conhecimento tendo em vista melhoria da qualidade } \\
\text { de vida e conservação do meio ambiente. }\end{array}$ \\
\hline $\begin{array}{l}\text { Congresso Internacional de } \\
\text { Moscou (1987) }\end{array}$ & Internacional & $\begin{array}{l}\text { Difundi a educação ambiental por intermédio do desenvolvimento de currículo e } \\
\text { de materiais didáticos observando a conscientização, a formação por meio da } \\
\text { transmissão de informações, a preparação e desenvolvimento de hábitos e } \\
\text { habilidades para a tomada de decisões }\end{array}$ \\
\hline $\begin{array}{l}\text { Parecer do MEC Nº 226/87 } \\
\text { (1987) }\end{array}$ & Nacional & $\begin{array}{l}\text { Enfatiza a urgência da introdução da Educação Ambiental, propondo-se que fosse } \\
\text { iniciada "a partir da escola, numa abordagem interdisciplinar, levando à população } \\
\text { posicionamento em relação a fenômenos ou circunstâncias do ambiente" }\end{array}$ \\
\hline $\begin{array}{l}\text { Promulgação da } \\
\text { Constituição Federal } \\
\text { Brasileira (1988) }\end{array}$ & Nacional & $\begin{array}{l}\text { Garante o direito ao meio ambiente ecologicamente equilibrado e a } \\
\text { responsabilidade da Nação em garanti-lo aos cidadãos. Promoção da EA em todos } \\
\text { os níveis de Ensino. }\end{array}$ \\
\hline $\begin{array}{l}\text { Criação do Fundo Nacional } \\
\text { de Meio Ambiente (1989) }\end{array}$ & Nacional & Promove o apoio aos projetos na área da EA \\
\hline $\begin{array}{l}\text { Conferência de Jomtein } \\
\text { (1990) }\end{array}$ & Internacional & Reforço do compromisso de educar todo o cidadão do planeta \\
\hline $\begin{array}{l}\text { Portaria do } \mathrm{MEC} \mathrm{n}^{\circ} 678 / 91 \\
\text { (1991) }\end{array}$ & Nacional & $\begin{array}{l}\text { Estabelece que todos os sistemas e instituições de ensino no país devem adequar } \\
\text { seus currículos de modo a contemplar a EA }\end{array}$ \\
\hline $\begin{array}{l}\text { Criação do Ministério do } \\
\text { Meio Ambiente (1992) }\end{array}$ & Nacional & $\begin{array}{l}\text { Formula e implementa políticas públicas no território nacional conjuntamente com } \\
\text { a sociedade em vista da promoção do desenvolvimento sustentável }\end{array}$ \\
\hline $\begin{array}{l}\text { Instituição dos núcleos de } \\
\text { EA em todos os Estados do } \\
\text { País (1992) }\end{array}$ & Nacional & $\begin{array}{l}\text { Desenvolve Políticas Públicas em território Nacional e fomentar os debates } \\
\text { relacionados a Conferência Mundial (Rio-92) }\end{array}$ \\
\hline $\begin{array}{l}\text { Conferência das Nações } \\
\text { Unidas sobre o Meio } \\
\text { Ambiente e } \\
\text { Desenvolvimento Rio-92 } \\
\text { (1992) }\end{array}$ & $\begin{array}{l}\text { Nacional e } \\
\text { Internacional }\end{array}$ & $\begin{array}{l}\text { Visa discutir e estabelecer acordos e estratégias em nível global visando o } \\
\text { desenvolvimento econômico e a responsabilidade com a sustentabilidade } \\
\text { ambiental. }\end{array}$ \\
\hline $\begin{array}{l}\text { Carta Brasileira para a } \\
\text { Educação Ambiental } \\
(1992)\end{array}$ & Nacional & $\begin{array}{l}\text { Reflete sobre importância da EA para a sociedade sustentável e responsabilidade } \\
\text { global e intensifica as discussões sobre a sua implantação no ensino superior. }\end{array}$ \\
\hline $\begin{array}{l}\text { Criação do Programa } \\
\text { Nacional de Educação } \\
\text { Ambiental-PRONEA } \\
\text { (1994) }\end{array}$ & Nacional & $\begin{array}{l}\text { Promove discussões sobre a organização e efetivação da EA no país, levando em } \\
\text { consideração } 3 \text { linhas principais: capacitação de gestores e educadores, } \\
\text { desenvolvimento de ações educativas, e desenvolvimento de instrumento e } \\
\text { metodologias. }\end{array}$ \\
\hline $\begin{array}{l}\text { Conferência de Tessalônica } \\
\text { (1997) }\end{array}$ & Internacional & Discute a promoção da educação e da conscientização para a sustentabilidade. \\
\hline
\end{tabular}




\begin{tabular}{|c|c|c|}
\hline $\begin{array}{l}\text { Publicação dos PCN'S } \\
\text { (1997) }\end{array}$ & Nacional & $\begin{array}{l}\text { Direciona a instituição de ensino na elaboração da proposta de ensino e } \\
\text { aprendizagem a partir de temáticas que devem ser desenvolvidas levando em } \\
\text { consideração a realidade dos alunos e o contexto escolar }\end{array}$ \\
\hline $\begin{array}{l}1^{\text {a }} \text { Conferência de } \\
\text { Educação Ambiental no } \\
\text { Brasil (1997) }\end{array}$ & Nacional & $\begin{array}{l}\text { Discute os rumos da EA e enfatiza a necessidade de reorganização das práticas } \\
\text { pedagógicas e organização curricular em vista de promover a educação pautada no } \\
\text { caráter holístico. }\end{array}$ \\
\hline $\begin{array}{l}\text { Diretrizes Curriculares } \\
\text { Nacionais para o Ensino } \\
\text { Fundamental (1998) }\end{array}$ & Nacional & $\begin{array}{l}\text { Aponta temáticas para que sejam desenvolvidas no ensino fundamental de todo o } \\
\text { país resguardando as especificidades de cada lugar. }\end{array}$ \\
\hline $\begin{array}{l}\text { Aprovação da Lei Federal } \\
n^{\circ} 9.795 / 1999\end{array}$ & Nacional & $\begin{array}{l}\text { Institui a Política Nacional de Educação Ambiental, apresenta conceituação do que } \\
\text { compreende-se por ela, e propõe diretrizes pelas quais seu desenvolvimento deve } \\
\text { reger-se. }\end{array}$ \\
\hline $\begin{array}{l}\text { Conferência de } \\
\text { Joanesburgo/Rio+10 } \\
(2002)\end{array}$ & Internacional & $\begin{array}{l}\text { Avalia as ações realizadas desde a Rio/92 e propõe efetivação e maior } \\
\text { envolvimento nas linhas de trabalho. Ademais, reitera o papel fundamental da } \\
\text { educação nos processos propostos para a sustentabilidade. }\end{array}$ \\
\hline $\begin{array}{l}\text { Reorganização do } \\
\text { Programa Nacional de } \\
\text { Educação Ambiental } \\
\text { (2004) }\end{array}$ & Nacional & $\begin{array}{l}\text { Apregoa o caráter prioritário em permanente da EA no país e amplia a reflexão } \\
\text { para a interação e integração de múltiplas dimensões ambiental, levando em } \\
\text { consideração as perspectivas ecológica, social, ética, cultural, econômica, espacial } \\
\text { e política. }\end{array}$ \\
\hline Rio+20 (2012) & $\begin{array}{l}\text { Nacional e } \\
\text { Internacional }\end{array}$ & $\begin{array}{l}\text { Renovação dos compromissos com o desenvolvimento sustentável e erradicação } \\
\text { da pobreza. }\end{array}$ \\
\hline $\begin{array}{l}\text { Resolução }{ }^{\circ} 02 \text {, de } 15 \text { de } \\
\text { junho de } 2012 \text {, estabelece } \\
\text { as Diretrizes Curriculares } \\
\text { Nacionais para a Educação } \\
\text { Ambiental }\end{array}$ & Nacional & $\begin{array}{l}\text { Estabelece as Diretrizes Curriculares Nacionais para a Educação Ambiental, } \\
\text { apresentando-se como referência para a promoção da Educação Ambiental em } \\
\text { todos os níveis e modalidades do Ensino Formal no Brasil. }\end{array}$ \\
\hline $\begin{array}{l}\text { Programa Nacional de } \\
\text { Escolas Sustentáveis - } \\
\text { versão preliminar (2014) }\end{array}$ & Nacional & $\begin{array}{l}\text { Estimular a escola como espaços educadores sustentáveis, por meio da articulação } \\
\text { entre currículo, espaço físico/edificações, gestão e relações escola-comunidade. }\end{array}$ \\
\hline 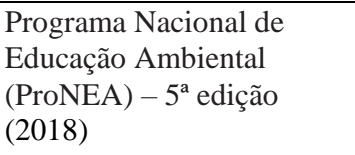 & Nacional & $\begin{array}{l}\text { Atualização dos marcos legais e normativos e a indicação de novos caminhos } \\
\text { necessários frente aos desafios para reafirmar o compromisso e a participação no } \\
\text { desenvolvimento da Educação Ambiental, com vista a ações promotoras da } \\
\text { sustentabilidade no país. }\end{array}$ \\
\hline
\end{tabular}

Fonte: Autores

A partir dos dados elencados observou-se que a agenda da Educação Ambiental no Brasil está em constantes transformações, (re) formulações e (re) construção a qual se infere a Educação Ambiental como dimensão da educação possui uma força importante para o processo de sensibilização e conscientização nas relações que emergem entre homem, sociedade e natureza e deve ocupar cada vez mais espaços na educação formal, não formal e informal e nas Políticas Públicas que aponte a problemática ambiental para a humanização a transformação social.

\section{Referências}

Barbieri, J. C., \& Silva, D. (2011). Desenvolvimento sustentável e educação ambiental: uma trajetória comum com muitos desafios. RAM. Revista de Administração Mackenzie, São Paulo, SP, 12(3), 51-82.

Brasil (1973). Decreto 70.030/73. Dispõe sobre a criação da secretaria especial de Meio Ambiente.

BRASIL. (1977). Secretaria Especial do Meio Ambiente. Educação Ambiental. Brasília, DF.

BRASIL. (1988). Constituição da República Federativa do Brasil de 1988.

Brasil. (1997). Secretaria de Educação Fundamental. Parâmetros Curriculares Nacionais: Ensino de 1a à $4 a$ série e 5 a à 8 a série. Brasília: MEC/SEF.

BRASIL. (1998). Parâmetros Curriculares Nacionais: terceiro e quarto ciclo: apresentação de temas transversais. Brasília: MEC/SEF, 1998.

BRASIL. (1998). A Implantação da Educação Ambiental no Brasil. Brasília: Ministério da Educação e do Desporto, 1998.

BRASIL. (1998b). Ministério da Educação e do Desporto. Conselho Nacional de Educação. Câmara da Educação Básica. Resolução n. 2 , de 7 abril de 1998. Institui as Diretrizes Curriculares Nacionais para o Ensino Fundamental. Diário Oficial da União. Brasília, DF, 15 abr.

Brasil. (1999). Política Nacional de Educação Ambiental, Lei 9795. Diário Oficial da República Federativa do Brasil, Brasília, DF. 
BRASIL (2001). Confederação das Nações Unidas sobre Meio Ambiente e Desenvolvimento. AGENDA 21. (3ª ed.): Senado Federal, Subsecretaria de Edições Técnicas, p. 287-374; 533-546.

BRASIL. (2005). Programa nacional de educação ambiental: ProNEA. ( $3^{\mathrm{a}}$ ed.): Ministério do Meio Ambiente.

Brasil (2012). Resolução n. ${ }^{\circ}$ 02. Estabelece as Diretrizes Curriculares Nacionais para a Educação Ambiental. Ministério da Educação, Conselho Nacional da Educação, Brasília, DF.

Brasil. (2013). Resolução n. ${ }^{\circ}$ 18. Dispõe sobre a destinação de recursos financeiros, nos moldes operacionais e regulamentares do Programa Dinheiro Direto na Escola-PDDE. Ministério da Educação, Fundo Nacional de Desenvolvimento da Educação, Brasília, DF.

Brasil. (2014). Programa Nacional de Escolas Sustentáveis. Versão preliminar. Ministério da Educação. Brasília, DF.

Brasil. (2018). Programa Nacional de Educação Ambiental. Ministério do meio Ambiente. Educação Ambiental por um Brasil sustentável: ProNEA, marcos legais e normativos [recurso eletrônico]. Ministério do Meio Ambiente - MMA/Ministério da Educação - MEC. Brasília-DF: MMA.

Calado, S. S., \& Ferreira, S. C. R. (2005). Análise de Documentos: método de Recolha e Análise de Dados. Metodologia de Investigação I. Departamento de Educação da Faculdade de Ciências da Universidade de Lisboa.

Corrêa do Lago, A. A. (2007). Estocolmo, Rio, Joanesburgo: Brasil e as Três Conferências Ambientais das Nações Unidas. Brasília, DF: FUNAG.

Duarte, L. C. B. (2003). Política externa e meio ambiente: Zahar.

Estocolmo. (1972). Conferência das nações unidas para o meio ambiente humano, Suécia: Estocolmo, 1972. Declaração de Estocolmo. Suécia.

Ferrari, A. H. (2014). De Estocolmo, 1972 a Rio+20, 2012: O discurso ambiental e as orientações para a educação ambiental nas recomendações internacionais. 2014. Tese (Doutorado) Programa de Pós-Graduação em Educação Escolar da Faculdade de Ciências e Letras da Universidade Estadual Paulista "Júlio de Mesquita Filho" - Campus de Araraquara., Araraquara, SP.

França, J. F. B. F. (2010). A Política Externa Brasileira Para o Meio Ambiente: De Estocolmo a Joanesburgo. Cadernos De Relações Internacionais, Rio de Janeiro, RJ, 3(1), 1-31.

Higgs, J., \& Cherry, N. (2009). Doing qualitative research on practice. In: Higgs, J., Horsfall, D., Grace, S. (Eds.). Writing Qualitative Research on Practice. Rotterdam (NE): SensePublishers, p. 3-12.

Loureiro, C. F. B. (2012). Trajetórias e fundamentos da educação ambiental. (4ª ed.): Cortez, 2012.

Ludke, M., \& André, M. (2015). Pesquisa em educação: abordagens qualitativas. E.P.U.

Moradillo, E. F., \& Oki, M. C. M. (2004). Educação ambiental na Universidade: Construindo possibilidades. Quimica Nova, [s. 1.], 27(2), $332-336$.

Morin, E. (2003). A cabeça bem-feita: repensar a reforma, reformar o pensamento. (8 $8^{\mathrm{a}}$ ed.): Bertrand Brasil, 2003.

Oliveira, G. C. T. (2013). Atividades de educação ambiental desenvolvidas no ensino fundamental em duas instituições do município de Assis Chateaubriand PR: entre o ideal da abordagem crítica e a realidade da corrente conservadora. 2013. Dissertação (Mestrado)- Programa de Pós Graduação em GeografiaUniversidade Estadual do Oeste do Paraná., Marechal Cândido Rondon, PR, 2013.

Onu (2002). Declaração de Joanesburgo sobre Desenvolvimento Sustentável. Johanesburgo.

Pádua, E. M. M. (1997). Metodologia de pesquisa: abordagem teórica-prática. (2ª ed): Papirus.

Ramos, E. C. (2001). Educação ambiental: origem e perspectivas. Editora da UFPR, Curitiba, PR, 18, 201-218.

Saccomani, R., \& Marchi, L. F. B.; Sanches, R. A. (2018). Primavera silenciosa: uma resenha. Revista Saúde em Foco, [s. 1.], 10, 739-748, 2018.

Silva, W. I., \& Oliveira, J. G. R. (2019). Práticas de Educação Ambiental nas aulas de geografia do ensino médio: reciclando velhos hábitos. Revista Brasileira de Educação Ambiental (RevBEA), São Paulo, SP, 14(1), 275-294.

Souza, J. N. S., \& Benevides, R. C. A. (2005). Educação Ambiental Para o Desenvolvimento Sustentável e o Comprometimento das Universidades / Faculdades do Município do Rio de Janeiro, RJ. II Simpósio de Excelência em Gestão e Tecnologia - SEGeT’2005, [s. 1.], p. 531-548.

Tbilisi. (1977). Conferência intergovernamental sobre educação ambiental aos países membros. Tbilisi, CEI, de 14 a 26 de out. de 1977.

Timoteo, C. K. (2016). Análise da inserção da educação ambiental no volume I do currículo do 6o ano / 5a série do ensino fundamental do Estado de São Paulo. 2016. Dissertação (Mestrado)-Programa de Pós- Graduação em Ciências Ambientais-Universidade Federal de São Carlos, São Carlos, SP.

Unesco. (1990). Declaração Mundial sobre Educação para Todos: satisfação das necessidades básicas de aprendizagem Jomtien. UNESCO, 1990.

Unesco/Pnuma. (1977). Seminário internacional de Educación Ambiental: Belgrado, Yugoslávia, 13-22 de octobre, 1975. Paris. 